\title{
HUBUNGAN PENGETAHUAN DENGAN PERILAKU HIDUP BERSIH SEHAT PADA REMAJA PUTRI
}

\author{
(Knowledge Relationships With Clean Healthy Behaviour In Young Women)
}

Dwi Rahayu, Ani Andriyani

\begin{abstract}
Clean living healthy behaviors (PHBs) to be one government program that is expected to complete a variety of diseases and health problems. Clean and comfortable environment that will reduce negative impacts on the environment.

This research design uses a Cross Sectional correlation approach. The population in this study were young women in the sixth grade girls cabin Ibtidaiyah Lirboyo as many as 62 teenagers. Studied sample of 53 adolescents using a sample random sampling technique. Independent variables in this study is the knowledge of clean healthy living, while the dependent variable is the behavior of a healthy clean life. Collecting data using questionnaires. Analyze data using Spearman Rank statistical test.

The results obtained (47.17\%) adolescents have adequate knowledge and category (45.28\%) adolescents have poor behavior category. The results of data analysis using the Spearman Rank statistical test at $\alpha=0.05$ obtained by the correlation coefficient 010 and a significant level of 0.432. This result means that there is no relationship of knowledge about healthy living clean with a clean healthy living behaviors in adolescent girls in the sixth grade girls cabin Lirboyo Elementary.

This study shows that the less knowledge about living a clean healthy then the less well their healthy hygienic behavior. This can be used as a picture or information to carry out further research related to environmental health.
\end{abstract}

Key words: Knowledge, Healthy Lifestyle Behavior, Teens

\section{Pendahuluan}

Berbicara tentang hidup sehat, dan bersih tidak lepas dari memahami tentang modernisasi, konsep sehat, derajat kesehatan masyarakat dan paradigma sehat. Konsep sehat sesungguhnya tidak terlalu mutlak dan universal karena ada faktor-faktor lain di luar kenyataan yang mempengaruhi terutama faktor sosial budaya (Ahyar M, 2007: 27).

Perilaku Hidup Bersih Sehat yang populer dengan istilah PHBS menjadi salah satu program pemerintah yang diharapkan mampu menyelesaikan berbagai penyakit dan masalah kesehatan. Terciptanya PHBS tersebut tentunya tidak bisa dilaksanakan secara sendirian oleh masyarakat. Dalam hal ini dibutuhkan kerjasama dengan berbagai pihak terkait. Peran tenaga kesehatan dalam hal ini menjadi sesuatu yang amat penting.

Indonesia saat ini menghadapi permasalahan masih tingginya angka penyakit infeksi kulit juga peningkatan penyakit degenerative. Menurut Depkes RI prevalensi skabies di Puskesmas seluruh Indonesia pada tahun 1986 adalah $4,6 \%-12,95 \%$ dan skabies menduduki urutan ketiga dari 12 penyakit kulit tersering. Di beberapa Negara berkembang prevalensi skabies sekitar $6 \%$ - $27 \%$ populasi umum dan cenderung tinggi pada anak-anak usia 3-5 tahun serta remaja.

Menurut pengakuan salah satu Remaja Putri Pondok Lirboyo yang terjun di bagian kesehatan mengatakan bahwa jumlah santri putri di pondok putri Ibtidaiyah Lirboyo berjumlah 62 orang. 
Dengan kasus skabies berkisar 11\% 14\%. Dan kasus terbanyak di tahun ini adalah penyakit muntaber berkisar $20 \%$. Dan kasus yang lain seperti DBD dan typoid berkisar 4-6\%. Sehingga dengan kita melihat banyaknya kasus yang terjadi di pondok Lirboyo, kita sebagai tenaga kesehatan perlu turun tangan untuk melihat pada kasus tersebut.

Dengan lingkungan yang kurang bersih, dan kurangnya pengetahuan tentang perilaku hidup bersih sehat maka akan menimbulkan dampak buruk di lingkungan serta pribadi setiap individu. Lingkungan yang kumuh juga akan menimbulkan berbagai macam penyakit menular seperti diare, demam berdarah, tipoid, muntaber dan sebagainya. Dapat pula terjadi pencemaran air minum yang disebabkan oleh limbah rumah tangga yang pembuangannya tidak jauh dari sumber air bersih. Dengan demikian akan menimbulkan masalah baru di lingkungan tersebut, yaitu lingkungan yang tidak sehat. Semua itu dapat terjadi karena perilaku hidup kurang bersih dan tidak sehat yang disebabkan oleh masyarakat karena kurangnya pengetahuan tentang PHBS. Maka dari itu mengembangkan Perilaku Hidup Bersih Sehat hendaknya benar-benar dipahami dan ditekuni oleh setiap individu. Dengan mewujudkan lingkungan yang bersih dan nyaman akan mengurangi dampak negatif pada lingkungan, serta mengurangi proses terjadinya wabah penyakit menular.

\section{Metode}

Desain penelitian yang digunakan menggunakan metode Corelational, yaitu mengkaji hubungan antara dua variabel antara tingkat pengetahuan remaja putri dan perilaku hidup bersih sehat remaja putri pondok Lirboyo dengan pendekatan "Cross Sectional" yaitu mengukur secara bersama antara pengetahuan dan perilaku hidup bersih sehat remaja putri. Populasi dalam penelitian ini adalah semua remaja putri di kelas VI Ibtidaiyah pondok Lirboyo berjumlah 62 orang. Teknik sampling dalam penelitian ini adalah menggunakan simple random sampling.

Variabel Independen Pengetahuan remaja putri pondok Lirboyo tentang PHBS dengan parameter Pengetahuan: Pengetahuan tentang PHBS remaja putri pondok Lirboyo meliputi: penggunaan air bersih, mencuci tangan dengan air bersih dan sabun, penggunaan jamban sehat, pemberantasan jentikdi rumah, makan buah dan sayur setiap hari, aktifitas fisik setiap hari dan tidak merokok di rumah. Variabel dependent Perilaku hidup bersih sehat remaja putri pondok Lirboyo. Data yang diperoleh selanjutnya dianalisis dengan menggunakan teknik statistik korelasi Spearman Rank.dengan $\rho$ value $<\alpha(0.05)$

\section{Hasil}

Distribusi responden didapatkan dari 53 remaja berdasarkan umur remaja putri dijelaskan bahwa hampir setengahnya responden $(47,16 \%)$ berumur $12-14$ tahun dan sebagian kecil responden $(9,43 \%)$ berumur $>16-18$ tahun. Distribusi remaja berdasarkan pernah tidaknya mendapat pengetahuan tentang PHBS sebagian besar remaja putri pernah mendapatkan pengetahuan tentang PHBS yaitu sebanyak 32 remaja $(60,37 \%)$ dan sebagian kecil remaja putri tidak pernah mendapat pengetahuan tentang PHBS yaitu sebanyak 21 remaja $(39,62 \%)$. Distribusi remaja berdasarkan dari mana memperoleh pengetahuan tentang PHBS hampir setengahnya remaja putri memperoleh pengetahuan dari teman / keluarga, yaitu sebanyak 11 remaja $(34,37 \%)$ dan sebagian kecil remaja putri memperoleh pengetahuan dari pendidikan formal, yaitu sebanyak 5 remaja $(15,62 \%)$. Distribusi frekuensi responden berdasarkan pengetahuan tentang PHBS hampir setengahnya remaja putri mempunyai pengetahuan kategori cukup, yaitu sebanyak 25 remaja $(47,17 \%)$ dan sebagian kecil remaja putri mempunyai pengetahuan kategori baik, yaitu sebanyak 13 remaja $(24,53 \%)$. Distribusi frekuensi 
responden berdasarkan perilaku hidup bersih sehat hampir setengahnya remaja putri mempunyai perilaku hidup berih sehat kategori kurang, yaitu 24 remaja $(45,28 \%)$ dan sebagian kecil remaja putri mempunyai perilaku hidup bersih sehat kategori cukup, yaitu 11 remaja (20,75\%).
Hubungan pengetahuan tentang PHBS dengan perilaku hidup bersih sehat remaja putri kelas VI Ibtidaiyah Pondok Lirboyo.Tabulasi silang pengetahuan dengan perilaku hidup bersih sehat pada remaja putri pondok putri di kelas VI Ibtidaiyah Lirboyo .

Tabel 1 : Hubungan Pengetahuan dengan Perilaku Hidup Sehat pada remaja putri pondok Lirboyo.

\begin{tabular}{|c|c|c|c|c|c|c|c|c|}
\hline \multirow{3}{*}{ Pengetahuan } & \multicolumn{6}{|c|}{ Perilaku } & \multirow{2}{*}{\multicolumn{2}{|c|}{ Total }} \\
\hline & \multicolumn{2}{|c|}{ Kurang baik } & \multicolumn{2}{|c|}{ cukup } & \multicolumn{2}{|c|}{ Baik } & & \\
\hline & $\sum$ & $\%$ & $\sum$ & $\%$ & $\sum$ & $\%$ & $\sum$ & $\%$ \\
\hline Kurang baik & 6 & 11,3 & 2 & 3,8 & 7 & 13,2 & 15 & 28,3 \\
\hline Cukup & 16 & 30,2 & 5 & 9,4 & 4 & 7,5 & 25 & 47,2 \\
\hline Baik & 2 & 3,8 & 4 & 7,5 & 7 & 13,2 & 13 & 24,5 \\
\hline Total & 24 & 45,3 & 11 & 20,7 & 18 & 34 & 53 & 100 \\
\hline
\end{tabular}

Dari tabel 1 dapat diketahui bahwa hampir setengahnya remaja putri pondok putri di kelas VI Ibtidaiyah Lirboyo memiliki pengetahuan tentang hidup bersih sehat kategori cukup dengan perilaku hidup bersih sehat kategori kurang baik yaitu sebanyak 16 remaja putri $(30,2 \%)$. Sedangkan sebagian kecil $(3,8 \%)$ remaja putri memiliki pengetahuan tentang hidup bersih sehat dengan kategori baik dengan perilaku hidup bersih sehat kategori kurang baik yaitu sebanyak 2 remaja putri dan memiliki pengetahuan tentang hidup bersih sehat dengan kategori kurang baik dengan perilaku hidup bersih sehat kategori cukup. Berdasarkan hasil uji tersebut didapatkan nilai signifikan sebesar 0,432 $>0,05$, maka $\mathrm{H} 0$ diterima dan $\mathrm{H} 1$ ditolak.

Kesimpulan: Tidak Ada Hubungan Pengetahuan Dengan Perilaku Hidup Bersih Sehat Pada Remaja Putri Pondok Putri di Kelas VI Ibtidaiyah Lirboyo.

\section{Pembahasan}

Sesuai dengan tujuan yang telah ditetapkan, maka pada bagian ini akan dibahas hasil penelitian yang telah dilaksanakan pada tanggal 19 Juli 2011.

\section{Pengetahuan tentang hidup bersih dan sehat remajaputri (pondok putri di kelas VI Ibtidaiyah Lirboyo).}

Berdasarkan hasil penelitian menunjukan bahwa sebagian besar remaja putri berpengetahuan cukup yaitu sebanyak 25 remaja $(47,17 \%)$ dan sebagian kecil remaja putri mempunyai pengetahuan kategori baik, yaitu sebanyak 13 remaja $(24,53 \%)$.

Pengetahuan merupakan hasil "tahu", terjadi setelah orang melakukan penginderaan/pengamatan terhadap suatu objek tertentu. Pengamatan terjadi melalui panca indera manusia, yaitu indera penglihatan, pendengaran, penciuman, perasa, dan peraba. Pengetahuan manusia sebagian besar diperoleh melalui mata dan telinga. Pengetahuan pada dasarnya terjadi dari sejumlah fakta dan teori yang memungkinkan seseorang untuk dapat memecahkan masalah yang dihadapinya (Notoatmodjo, 2005).

Pengetahuan tentang hidup bersih dan sehat harusnya sudah ditanamkan sejak dini sehingga dewasanya mampu menerapkan dalam kehidupan seharihari.Perlu kita ketahui bahwa pengetahuan tentang hidup bersih dan sehat tidak diperoleh dari keluarga saja 
namun dari pendidikan formal juga penting sehingga mampu kita terapkan dalam kehidupan sehari-hari, khususnya bagi anak pondok.Karena kehidupan di pondok tidak seperti di rumah yang hanya terdiri dari beberapa orang saja. Pondok adalah tempat hidupnya masyarakat besar yang berteduh dalam satu gedung sehingga hidup bersih sehat haruslah bisa kita terapkan.

Faktor-faktor yang mempengaruhi pengetahuan meliputi faktor internal dan faktor eksternal. Faktor internal yaitu kematangan, usia, perbedaan jenis kelamin, kapasitas mental, kondisi kesehatan jasmani, kondisi kesehatan rohani, motivasi, pengalaman sebelumnya. Sedangkan faktor eksternal yaitu lingkungan, bimbingan belajar, kondisi-kondisi intensif, dan informasi (W. Soemanto, 2007: 28).

Berdasarkan penelitian di pondok putri kelas VI Ibtidaiyah Lirboyo dari 53 remaja putri didapatkan bahwa hampir setengahnya remaja putri berumur 12-14 tahun yaitu sebanyak $(47,16 \%)$ dan sebagian kecil berumur $>16-18$ tahun, yaitu sebanyak 5 remaja $(9,43 \%)$

Pada usia 12-13 tahun, masa ini disebut juga masa pueral, yaitu masa peralihan dari kanak-kanak ke remaja. Pada anak perempuan, masa ini lebih singkat dibandingkan dengan anak lakilaki.Perkembangan intelektualitas yang sangat pesat terjadi pada fase ini (Ahyar M, 2011: 12).

Namun kenyataannya tidak sesuai dengan teori.Dari hasil penelitian yang dilakukan pada remaja putri di pondok putri kelas VI Ibtidaiyah Liroyo pengetahuan mereka kategori cukup, dalam arti pengetahuan mereka sedang. Padahal teorinya usia 12-13 tahun perkembangan intelektualnya tinggi. Remaja putri pondok sangat jarang mendapat penyuluhan tentang kesehatan sehingga pengetahuan mereka tentang hidup bersih sehat masih kurang.

Pada usia 14-16 tahun, masa ini disebut juga masa remaja awal, perasaan sosial remaja di masa ini semakin kuat, dimana usia ini usia remaja mencari identitas (Ahyar $\mathrm{M}$, 2011: 12).

Masa-masa ini remaja sangat menjaga penampilannya,dan seharusnya lebih menjaga kebersihan diri mereka karena ingin selalu terlihat sempurna. Tapi kenyataannya, dari hasil penelitian kami remaja-remaja pondok seakan tidak peduli dengan penampilan mereka, bahkan mereka ganti baju 2 hari sekali bahkan lebih, mereka lebih pede dengan pakaian has pondok yang ala kadarnya. Dengan kebiasaan mereka yang jarang ganti baju dapat menimbulkan penyakit gatal-gatal atau skabies.Bahkan mereka menganggap penyakit ini adalah penyakit yang sudah melekat dengan anak pondok.Ini adalah salah.Ini pertanda kurangnya pengetahuan mereka tentang hidup bersih sehat.

Pada usia 17-18 tahun, masa ini kematangan psikologis dan mental mereka belum tercapai sepenuhnya (Ahyar M, 2011: 12).

Masa ini sudah mendekati dewasa, sehingga pola pikirnya pun seharusnya lebih matang dari usia sebelumnya. Namun kenyataan yang saat ini terjadi pada remaja putri pondok hampir tidak sesuai dengan teorinya. Remaja putri dalam usia ini sebanyak 5 orang masih lebih baik daripada remaja yang usia di bawahnya.

Remaja putri ini sudah pernah mendapat pengetahuan tentang hidup bersih sehat namun masih belum mencapai sepenuhnya, dan mereka masih belum bisa menerapkannya dalam kehidupan sehari-hari.Ada beberapa faktor yang mempengaruhi diantaranya lingkungan tempat mereka, dan keadaan lingkungannya.Jumlah remaja putri sekitar 708 orang dan 
fasilitas kamar mandi yang disediakan hanya berjumlah 10 kamar mandi.Sehingga menyebabkan mereka kadang malas untuk mandi, di karenakan harus mengantri dahulu.

Remaja putri yang pernah mendapat informasi tentang hidup bersih dan sehat sebanyak 32 remaja $(60,37 \%)$ dan yang tidak pernah mendapat pengetahuan tentang hidup bersih dan sehat sebanyak 21 remaja $(39,62 \%)$. Hampir setengahnya remaja memperoleh pengetahuan dari teman / keluarga sebanyak 22 remaja $(41,50 \%)$ dan sebagian kecil memperoleh pengetahuan tentang hidup bersih dan sehat dari pendidikan formal yaitu sebanyak 5 remaja $(9,43 \%)$.

Faktor media masa meliputi bioskop, TV, surat kabar, majalah, buku-buku yang ada disekeliling kita akan menghambat belajar bila anak terlalu banyak waktu yang dipergunakan untuk itu, hingga lupa akan tugas belajar (W. Soemanto, 2007: 28).

Di pondok hal yang di atas tidak disediakan. Itupun sudah menghambat mereka untuk memperoleh pengetahuan tentang hidup bersih sehat,karena mereka lebih di sibukkan dengan kegiatan rutinitas pondok, seperti ngaji, belajar agama, sholat berjamaah dan lain-lain. Di sela waktuwaktu luangnya tidak mereka gunakan untuk memperoleh pengetahuan karena fasilitas buku-buku umum sangat jarang untuk disediakan.Di pondok pun jarang diadakannya penyuluhan mengenai kesehatan, padahal pondok Lirboyo sudah memiliki klinik sendiri yang di dalamnya adalah orang-orang kesehatan tapi tidak pernah terjun langsung untuk memberi penyuluhan pada santri-santri pondok (pengakuan salah satu pengurus pondok putri).

\section{Perilaku Hidup Bersih Sehat (PHBS)}

Berdasarkan hasil penelitian perilaku hidup bersih sehat menunjukkan bahwa hampir setengahnya remaja berperilaku kategori kurang baik yaitu 24 remaja putri $(45,3 \%)$ dan sebagian kecil remaja berperilaku kategori cukup yaitu 11 remaja $(20,75 \%)$.

Perilaku hidup bersih sehat (PHBS) adalah tindakan yang dilakukan oleh perorangan, kelompok, atau masyarakat yang sesuai dengan norma-norma kesehatan, menolong dirinya sendiri dan berperan aktif dalam pengembangan kesehatan untuk memperoleh derajat yang setinggitingginya (Dinas Kesehatan Provensi Sulawesi Tengah, 2007).

Namun karena kehidupan di pondok sangat berbeda dengan kehidupan di rumah, karena banyaknya jumlah orang yang tinggal dalam satu atap pondok dan fasilitas umum yang tersedia sangat minim, serta kesadaran mereka tentang kesehatan masih kurang sehingga menghambat mereka untuk mempraktekkan perilaku hidup bersih dan sehat. Contohnya dalam membersihkan kamar, kalau bukan yang piket maka yang lain enggan untuk membersihkannya, walau mereka melihat keadaan kamarnya berantakan atau kotor. Sifat cuek dalam diri mereka masih tinggi, dan masih sangat sering kita jumpai dalam kehidupan anak pondok.

Faktor-faktor yang mempengaruhi perilaku terdiri dari faktor internal dan faktor eksternal.Faktor internal yang bersifat bawaan, seperti tingkat kecerdasan, tingkat emosional, jenis kelamin.Faktor eksternal yang terdiri dari lingkungan fisik, sosial budaya, ekonomi, politik, dan sebagainya (Notoatmodjo, 2003: 126-127).

Pondok adalah fasilitas umum yang digunakan oleh orang banyak, karena merasa bukan miliknya sehingga kesadaran mereka untuk menjaganya masih kurang. Lingkungan yang kotor akan tetap kotor sampai orang yang terjadwal piket 
membersihkannya. Dari hal ini bisa kita lihat bahwa kesadaran anak pondok dengan hidup bersih sehat masih kurang.

Seharusnya anak pondok bisa mempraktekkan perilaku hidup bersih dan sehat. Hal ini dapat terlaksana apabila dalam diri tiap individu telah ditanamkan perilaku hidup bersih dan sehat dan memiliki kesadaran akan pentingnya hidup bersih dan sehat. Tanggap dengan kondisi sekitarnya, jika melihat keadaan lingkungan yang kurang pas dengan kesehatan ia mampu mengepaskan hal tersebut, mampu melihat dan memandang keadaan lingkungan tempat tinggalnya. Tidak acuh dengan keadaan lingkungan yang tidak sehat.Sehingga dengan keadaan lingkungannya mampu mewarnai perilakunya. Kenyataan yang terjadi tidak sesuai dengan harapan kita sebagai tenaga kesehatan, karena kurangnya kesadaran tiap individu untuk menjaga lingkungan sekitar mereka.

\section{Hubungan Pengetahuan dengan Perilaku Hidup Bersih Sehat pada Remaja Putri Pondok Putri di Kelas VI Ibtidaiyah Lirboyo}

Berdasarkan hasil tabulasi data diperoleh bahwa sebagian besar remaja berpengetahuan cukup dan berperilaku kurang baik yaitu sebanyak 16 remaja. Untuk itu setelah dilakukan uji statistik SPSS Spearman Rank diperoleh nilai signifikan sebesar 0,432 dengan $\alpha 0,05$ maka $\mathrm{H} 0$ diterima dan $\mathrm{H} 1$ ditolak yang berarti tidak ada hubungan pengetahuan dengan perilaku hidup bersih sehat pada remaja putri di kelas VI Ibtidaiyah Lirboyo.

Dari pengalaman dan penelitian terbukti bahwa perilaku yang di dasari oleh pengetahuan akan lebih langgeng daripada perilaku yang tidak didasari oleh pengetahuan (Notoatmodjo, 2003).
Dari tabulasi silang pengetahuan dengan perilaku hidup bersih sehat menunjukan bahwa hampir setengahnya remaja putri pondok putri di kelas VI Ibtidaiyah Lirboyo memiliki pengetahuan tentang hidup bersih sehat kategori cukup dengan perilaku hidup bersih sehat kategori kurang baik yaitu sebanyak 16 remaja putri $(30,2 \%)$. Sedangkan sebagian kecil $(3,8 \%)$ remaja putri memiliki pengetahuan tentang hidup bersih sehat dengan kategori baik dengan perilaku hidup bersih sehat kategori kurang baik yaitu sebanyak 2 remaja putri dan memiliki pengetahuan tentang hidup bersih sehat dengan kategori kurang baik dengan perilaku hidup bersih sehat kategori cukup.

Pengetahuan remaja putri di pondok putri tentang hidup bersih sehat masih dalam kategori cukup, namun perilaku hidup bersih sehat mereka masih kurang baik.Hal ini terjadi karena masih ada beberapa faktor yang tidak mendukung terbentuknya perilaku hidup bersih sehat pada remaja putri.Faktor yang tidak mendukung diantaranya faktor lingkungan, baik lingkungan fisik maupun sosial budaya, karena fasilitas umum yang tersedia masih minim dan remaja yang mondok berasal dari berbagai daerah sehingga untuk menyatukan pemikiran dan perilaku tiap individu masih sangat sulit.

Ada beberapa faktor yang mempengaruhi perilaku manusia diantaranya faktor Internal yaitu merupakan karakrteristik orang yang bersangkutan yang bersifat bawaan. Misalnya tingkat kecerdasan, tingkat emosional, jenis kelamin dan sebagainya.Faktor eksternal yaitu lingkungan, baik lungkungan fisik, sosial budaya, ekonomi, politik dan sebagainya.Faktor lingkungan ini sering merupakan faktor yang dominan yang mewarnai perilaku seseorang. Perilaku manusia terbagi menjadi 3 
dominan yaitu Kognitif (cognitive), afektif (afektive), psikomotor (Psychomotor) (Notoatmodjo, 2003 : 126-127)

Seharusnya di pondok sering diadakan penyuluhan tentang kesehatan agar perilaku hidup bersih sehat dapat terbentuk, walau tidak langsung dapat merubah perilaku mereka tapi sedikit demi sedikit akan merubah perilaku mereka. Faktor kognitif, afektif, serta psikomotor saling berkaitan. Jika kognitif / pengetahuannya kurang maka akan mempengaruhi sikapnya sehingga dapat tercermin dalam perilakunya.

\section{Kesimpulan}

1. Berdasarkan hasil penelitian pada pengetahuan tentang hidup bersih sehat pada remaja putri didapatkan bahwa sebagian besar remaja putri mempunyai pengetahuan kategori cukup yaitu sebanyak 25 remaja putri $(56,60 \%)$ dan sebagian kecil remaja putri mempunyai pengetahuan kategori kurang baik, yaitu sebanyak 13 remaja $(24,53 \%)$. Hal ini dikarenakan waktu mereka sangat padat dalam menimbah ilmu agama sehingga seakan mereka tidak ada waktu luang untuk menyempatkan membaca buku-buku mengenai pengetahuan tentang kesehatan serta mereka sangat jarang memperoleh penyuluhan mengenai kesehatan selama mereka di pondok.

2. Berdasarkan hasil penelitian pada perilaku tentang hidup bersih sehat remaja putri didapatkan bahwa hampir setengahnya berperilaku kurang baik yaitu sebanyak 24 remaja putri $(45,28 \%)$. Hal ini terjadi karena keadaan lingkungan yang tidak mendukung serta fasilitas umum yang disediakan di pondok masih sangat kurang.

3. Hasil uji statistik Spearman Rank didapatkan $\rho$ value $=0,432$ sehingga $>\alpha(0,05)$ yang artinya tidak ada hubungan pengetahuan tentang hidup bersih sehat dengan perilaku hidup bersih sehat pada remaja putri. Hal ini terjadi karena masih ada beberapa faktor yang tidak mendukung terbentuknya perilaku hidup bersih sehat pada remaja putri. Faktor yang tidak mendukung

\section{Saran}

Hasil penelitian ini dapat dijadikan masukan untuk mengambil kebijakan di pondok guna meningkatkan kesehatan lingkungan di pondok.Misalnya dengan penambahan kamar mandi yang sesuai dengan kapasitas anak pondok, 1 kamar mandi minimal digunakan oleh 15-20 anak.Serta memudahkan tenaga kesehatan dalam perijinan bila ingin mengadakan penyuluhan.

\section{Daftar Pustaka}

Arikunto S, 2003. Prosedur Penelitian Suatu Pendekatan Praktek. Surabaya Salemba Medika

Akper Dharma Husada, 2010. Pedoman Penyusunn Karya Tulis Ilmiah. Kediri.

Ahyar M, 2007. Makalah Cinta Alam Indonesia. Jatim: Manshurin

Ahyar M, 2011. Makalah Cinta Alam Indonesia. Jatim: Manshurin

Arikunto, Suharsani. (2002). Prosedur Penelitian Suatu Pendekatan Praktek: Cet.12. Jakarta: Rineka Cipta

Arsip kuliah pendidikan. 2007. Self Assessmen.

(http://www.mailarchive.com/majelimuda @ yahoogroups.com/msg02493.htmI 11-5-2008. Diakses tanggal 09 Juli 2011

Azwar, Saifuddin. (2005). Sikap Manusia Teori dan Pengukurannya. Yogyakarta: Pustaka Palajar

Dinas Kesehatan Kota Kediri, 2008.Buku Perilaku Hidup dan Sehat di Rumah Tangga. Bakti Husada

Dinas Kesehatan Provinsi Sulawesi Tengah, 2007.Buku Perilaku Hidup 
dan Sehat di Rumah Tangga. Bakti Husada

Fatimah, Enung. 2006. Psikologiperkembangan. Bandung: CV Pustaka Setia.

Hidayat, Aziz Alimul. (2007). Risat Keperawatan Dan Teknik Penulisan Ilmiah. Jakarta: Salemba Medika

Manshurin, 2007. Peran Tenaga Kesehatan Masyarakat dalam Mengubah Perilaku Masyarakat Menuju Hidup Bersih Sehat. (http://dinkesbonebolango.com).

Diakses pada 29 Januari 2009.

Notoatmodjo, 2007. Kesehatan Masyarakat Ilmu dan Seni. Jakarta: Rineka Cipta.

Nursalam, 2003. Konsep dan Penerapan Metodelogi Penelitian Ilmu Keperawatan. Jakarta: Salemba Medika.

Nursalam. (2008). Konsep Penerapan Metodologi Penelitian Ilmu Keperawatan. Jakarta: EGC 